Vol. 7, No. 1, 2021

Larysa Shuldan

\title{
IMPROVING THE ENERGY EFFICIENCY OF ARCHITECTURAL SOLUTIONS IN CONTEXT OF CLIMATE CHANGE SCENARIOS
}

\author{
${ }^{1}$ PhD, Associate Professor of the Department of Architectural Design and Engineering \\ Lviv Polytechnic National University, Lviv \\ e-mail: shuldanlarisa@gmail.com \\ orcid: 0000-0003-4171-9807
}

Received: 15.03.2021 / Revised: 27.04.2021 / Accepted: 28.04.2021

(C) Larysa Shuldan, 2021

https://doi.org/10.23939/as2021.01.087

Astract. The global climate system shows signs of rapid changes called a Climatic Transition in specialized literature. The article has studied climate trends in territorial (global, macro-climatic, mesoclimatic, and micro-climatic) and time limits (historical overview; current state; long-term, medium-term, and short-term prospects). The most probable medium-term forecasts until 2050 have been taken as a basis. The climate data analysis for the previous 60 years has been carried out and continued by our research with linear averaging of data for 2009-2020, the dynamics of main parameters changes on the territory of Ukraine and for Lviv city have been determined. The main requirements for architectural solutions in various climatic conditions have been formulated. Correlation analysis of energy efficiency improvements in architecture and current external micro-climatic conditions has been performed. It has been proposed to make appropriate changes to the regulatory documents.

Key words: architectural climatology, climatic transition, construction climatology, energy efficiency improvement of architectural solutions, Lviv Polytechnic, the architecture of public buildings.

\section{Problem stating}

It is important to apply powerful modern knowledge and methods of architectural climatology to improve public buildings and their complex energy efficiency, This science being part of architectural physics is designed to reveal the connections between climatic conditions and the architecture of buildings and urban planning formations. The main directions of architectural climatology are outlined by Vytruvyy in the first of ten books (chapters I, II, IV, VI) (Vytruvyy, 1936). In the books, he named the main climatic factors that influence the formation of building architecture and the choice of urban planning solutions. The books have had wide influence starting from operational characteristics of buildings and ending with the creation of comfortable conditions for people. And well-thought-out architectural solutions can level out adverse external climatic influences and enhance positive ones. The priority of climate influence on architecture was also emphasized by Ukrainian authors. For example, V. Shcherbakivskyi stated: "Architecture, like other types of human creativity, has been influenced by various factors and in the first place by the climate and nature" (Shcherbakivskyi, 1910, chapter 5). The traditional architecture heritage demonstrates the result of climate and architecture interconnection. (Dyda, 2009). Architectural 
climatology as an applied science has developed rapidly (Gusev, 1983, p. 440), (Ed. Obolensky, 2005, p. 448) for the past decades in the form of numerous thorough studies (Myagkov and Alekseeva, 2016, p. 356), (Apatenko, 2011, p. 98) in connection with the actualization of energy saving in architecture. The application of basic information about factors in architecture should be considered in the following main aspects: urban planning; formative, architectural planning, compositional, and design aspects. Architectural climatology also studies the influence of architectural and urban planning solutions on the formation of the individual territory's micro-climate. Today it relies on architectural typology, general climatology, ecology, hygiene, economics, and aesthetics. Architect's proficiency in this field determines the quality of modern architecture in functional, aesthetic, and economic aspects (Shuldan, 2006). At one time, N. Foster noted: "Adaptability is one of the most important tools in sustainable architecture" (Foster, 2005). And climatological adaptability can become the main sign of design decisions sustainability. But architectural climatology itself as well as its teaching in architectural schools has several unresolved issues.

\section{The objective of the article}

The analysis of climate information sets the main search vectors for architectural solutions of public buildings with improved energy efficiency, allows them to be divided by the degree of impact and evaluate the results obtained, serves as an undeniably important background for designing the micro-climate of public complexes. Climatological indicators are considered separately and collectively in such a way that they can be used at all stages of architectural and construction design. Most scientific works devoted to energy saving in architecture are based on statement, interpretation, and use of the climatic variables officially specified in the State Standard (Minrehionbud Ukrainy, 2011). The author's participation in the State Standard development prompted further work on collecting and analyzing available data from various sources and studying scientific and reference literature on this topic. It also has encouraged an attempt to define prospects, identify dominant trends in climate change, and outline them in an abstract way below. The parameters variability and the main climate trends are analyzed in territorial (global, macro-climatic, meso-climatic, and micro-climatic) and time limits (historical overview, present, long-term, medium-term, and short-term perspective). The study will allow us to perform a correlation analysis of the initial conditions of architectural design with actual external micro-climatic conditions

\section{Results and discussions}

Climate change scenarios and the future of energy efficiency in architecture. The global climate change prospect is one of the most pressing challenges humanity is facing. During the development of global warming or Little Ice Age scenarios currently discussed, the main function of architecture remains to create the maximum possible protection and comfort for humans. Due to the development of energy efficiency, it is possible to achieve this in conditions of rising prices and depletion of traditional energy resources. According to the Intergovernmental Panel on Climate Change (IPCC), construction, renovation, and modernization of buildings are responsible for $19 \%$ of global greenhouse gas emissions (Larrochelle, 2015).

And yet, warming or cooling? In favor of each of the versions, many arguments and counterarguments have been given, specific reasons and hypothetical assumptions have been provided. Skeptics reject both (Stronskyi, 2006). At the end of the 20th century, it became apparent to professionals working in the meteorological industry that the global climate system was showing signs of rapid change. Many scientists believe that first, anthropogenic influence leads to a global increase in temperature on the Earth's surface (Weart, 2003), (Boichenko, 2007, p. 105-111), (ed. Burroughs, 2003). Temperature deviations from certain standards cause several consequences: changes in humidity and wind conditions of large regions, the amount and frequency of precipitation, etc. Other scientists cite data that indicate global warming and its consequences are rather the results of natural 
changes in climatic conditions (Akimenko et al., 2006). There are still others who claim that the climate has always been changeable. After all, over the past two thousand years, there have been three periods of global warming and three periods of cooling. The last of them ended in the first half of the XIX century (Krenke, et al., 1995). Climatic processes of cyclic repetition are directly related to the long period of M. Milankovich cycles. They explain the cooling of the Gulf Stream and the slowdown in its flow since 2011 which is a sure sign of the seriousness of the future problems. According to them, we are now experiencing warming, which in the long term will end in cooling. (Kim \& An, 2013, p. 9-19). Climate scientists in the United States and Great Britain confirm that the current stage of stable warming began at the turn of the XIX-XX centuries and is now gaining alarming rates (National Research Council of the National Academies, 2010, p. 204-216), (NRC, 2008, p. 2), (ed. Burroughs, 2003, p. 240).

According to the results of a set of experiments on climate modeling, by the end of the 21 st century, American scientists predicted an increase in average temperatures by $1.1{ }^{\circ} \mathrm{C}-6.4{ }^{\circ} \mathrm{C}$, compared to the average values of 1980-1999 (National Research Council of the National Academies, 2010, p. 223). These data are permanently updated, checked and, in this regard, forecasts of changes are adjusted (Alloisioa, Farniaa \& Khoroshiltsevaan, 2013), (McGann \& James, 2019). Secretary-General of the World Meteorological Organization Petteri Taalas has officially confirmed that global average temperatures have already increased by about $1.1{ }^{\circ} \mathrm{C}$ since the pre-industrial era and that oceans temperature is at an all-time high level (United Nations, 2020). However, the "global warming" term is not used in the European regulatory and program field, but mainly the concept of climate change is used (European Commission, 2009), (European Commission, 2019).

It can be said for sure that global climate scenarios do not have sustainable certainty. Forecasts and causes of climate change, that are made public from high stands, often become a bargaining chip in major political games and depend on the goal of the main beneficiaries. An example of this is the absence of ozone holes topic in the current discussion. Therefore, it is impossible to consider the changes prospects for a period comparable to the estimated life span of 100 years buildings, until the end of the century. Further research has taken into account the most reasonable warming trends for the future until 2050.

In Eurasia, medium-term forecasts for this period indicate a warming trend (Peeters \& Deketelaere, 2006). Changes in the warming trajectory in the macro-climatic field are usually determined by the average values of climatic variables based on 30-year observations (ed. Burroughs, 2003). Individual years or even decades may deviate from the long-term trend. It is impractical to consider short periods, for example, changes over the past 3-5 or 10 years. Therefore, an averaging period that minimizes the impact of temporary natural variability on ultra-short time scales and facilitates the analysis of medium-term trends has been chosen. Architects in all latitudes adapt their projects to the environment, offering sustainable solutions. This article has suggested and developed recommendations for the formation of initial design conditions for the territory of Ukraine.

Ukraine climatic conditions analysis as a basis for determining ways of energy saving in architecture. In the previous period, several typological requirements that had to be met and taken into account in the design process, fixed in building codes and regulations, were determined by climatological typology. The climate typology is based on architectural and construction climate zoning made based on the results of long-term measurements of meteorological elements of the climate by a network of Hydrometeorological Service Stations. By the climatic zoning, various house operation modes (geometric, closed, and open) are unified, each of which has appropriate spatial planning solutions, the presence of open and semi-open rooms, loggias, balconies, sun protection, and other elements. Currently, the principle of territory zoning has also been adopted, according to which the territory of Ukraine is divided into 2 temperature zones depending on the number of heating period degree-days (Minrehionbud Ukrainy, 2017.). Zoning involves only changing the design requirements for external enclosing structures of the building, regulating the minimum value of the total heat transfer resistance of structures during new construction, reconstruction, and major repairs. Such values are minimal, transitional to new and more 
stringent requirements for thermal insulation of enclosing structures, which should be introduced into the regulatory framework.

Ukraine's climate has proved extremely sensitive to global changes. This conclusion was made possible by the analysis of the following: maps of the average monthly air temperature and precipitation in Ukraine (Tsentralna heofizychna observatoriia imeni Borysa Sreznevskoho, 2020.), current DSTU-N B V.1.1-27:2010 Construction climatology (Minrehionbud Ukrainy, 2011), other regulatory and reference literature (Ukrainskyi hidrometeorolohichnyi instytut, 2013) and own research in the form of climate analysis of most cities of the country.

Natural and climatic factors that affect the energy balance of the building and the surrounding area include solar radiation, temperature regime, wind, the latitude of the area, landscape, and so on. These factors do not depend on humans and are closely related to the natural environment. The increase in air temperature on our territory has been observed since 1989 . Since then, it has increased by more than $1.5{ }^{\circ} \mathrm{C}$ in January and February. There has appeared a temperature increasing tendency in July and August, which leads to abnormal overheating of buildings, and creates a need for air conditioning of premises in summer. Winters are getting less snowy. The duration of snow cover retention has relatively decreased by almost a month. Precipitation distribution change is becoming more important than the total amount of precipitation. Uneven precipitation becomes normal with an increase in the number of sparse rains and, conversely, heavy downpours. In general, there is a reduction in the zones of moisture and moisture saturation of the soil. At the same time, the frequency of house flooding is growing.

The concept of the state policy in the field of climate change in Ukraine names the causes of climate change and the main tasks for their elimination. "Anthropogenic impact on the climate system is the dominant cause of warming, ... to avoid the catastrophic consequences of climate change, it is necessary to achieve a reduction in greenhouse gas emissions of such a scale as to keep global warming within $2{ }^{\circ} \mathrm{C}$." (Ministerstvo ekolohii ta pryrodnykh resursiv Ukrainy 2017, p. 1). For the architectural industry, among the indicated direction of problem-solving we have highlighted the most important ones: reducing anthropogenic emissions, increasing greenhouse gas absorption; transition to low-carbon development; climate change adaptation.

Meso-scale climatic regimes research (as illustrated by Lviv). Against the background of global and regional changes, it is important to track local climatic information, including observations, assessment, and modeling of climatic variables that can predict annual, ten-year, and multi-decade climatological changes. Meteorological observations at Lviv Polytechnic have been carried out since its foundation. In 1877, the metrological station together with the observatory was established in the newly built main building of the Tsisar-Royal Real School in Lviv, as it was called back then. The values of climatic variables have been observed and recorded here for almost 100 years. For a reason, Lviv appears, like no other city, in the norms of the Soviet period, namely in the SNiP (construction rules and regulations) and in two guises dated 1973: "Lviv" and "Lviv Polytechnic".

Employees of the Architectural Construction Department, which is now the Architectural Design and Engineering Department are working on the architectural climatology problems, as one of the main scientific fields. Professors Kinash R. I., Shvets Ya. V., assistant professor Kazakov H. V, assistant professor Shuldan L. O., Yatsiv M. B. (Shuldan, 2002), (Kinash\&Burnaiev, 2001), (Shuldan\&Yatsiv, 1998, 72-76 p.) have devoted their scientific and methodological works to certain problems of architectural climatology at different times. The staff of the department still owes the formation of the architectural physics laboratory with its unique equipment and installations to Bedyl O. T., Zapolskyi V. H., and Stasevych I. V. The architectural climatology section in the architectural physics course is one of the most important in the professional training of students of Architectural Specialties of Institute of Architecture and Design Lviv Polytechnic.

To identify climate changes on a meso-climatic scale, the author has conducted her research, analyzing the values of several local climatic variables for Lviv (Table 1). Since temporary deviations of parameter values from the climate norm cannot be considered as climate change, data from the following 
sources have been used for analysis: 1963 (State Committee of Council of Ministers of the Soviet Union of Construction [GKSM SSSR PDS], 1963), 1973 (GKSM SSSR PDS, 1973), 1982 (GKSM of the USSR PDS, 1983), 2000 (Gosstroy of Russia, 2000), (Minbud Ukrainy, 2006), and 2010 (Minrehionbud Ukrainy, 2011) with an averaging period of observation data from 1950 to 2008. The data processing of a later period has been based on averaging the values of the main climatic variables from 2009 to 2012 and from 2012 to 2020. Indicators are determined by data linear averaging and are not subjected to homogenization, as required by the method of creating homogeneous meteorological series (Skrynyk\& Skrynyk, 2011, p. 46-53). The basis for research practice, as in the formation of regulatory documents, was the reports of the Lviv Aeronautical Meteorological Station (TOV "Rozklad Pohody", 2020).

Table 1

\section{Examples of research of some external climatic variables (Lviv) during the heating period}

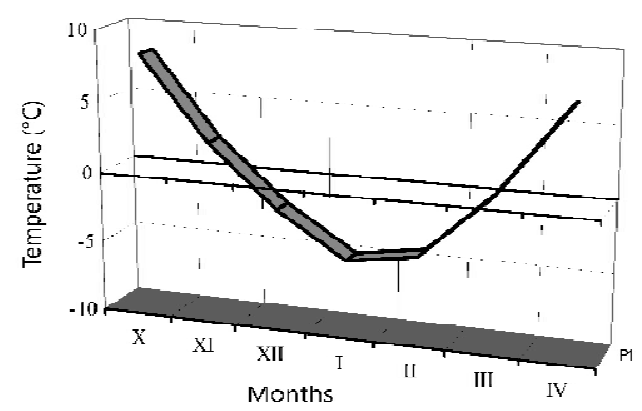

Fig. 1.1. Flow chart of average outdoor air temperatures in Lviv during the heating period (from October to April)

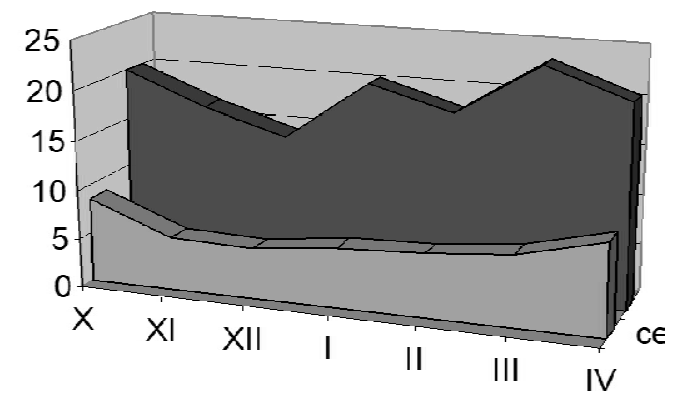

Fig. 1.3. Chart of maximum and average amplitudes of temperature oscillations in Lviv by months (from October to April)

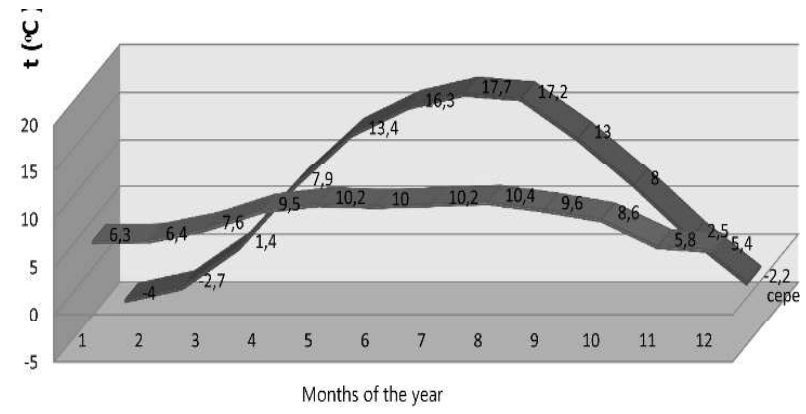

Fig. 1.2. Flow chart of average monthly outdoor air temperatures during the year in Lviv
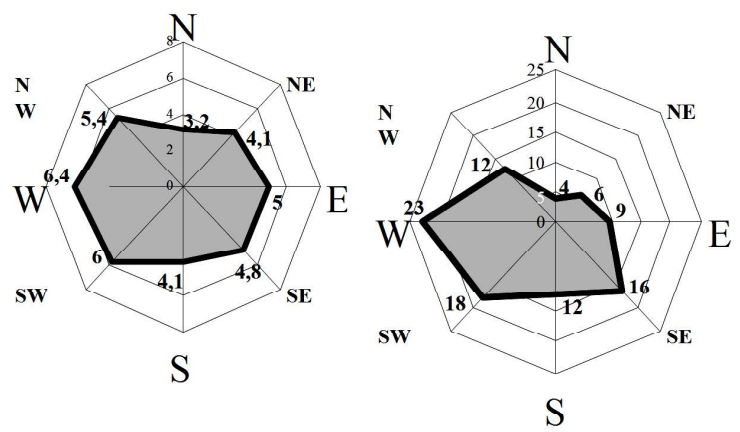

Fig. 1.4. Wind diagrams are built by: a) repetition;b) speed

The main temperature indicators used in energy calculations and thanks to which typological solutions and operating modes of buildings are chosen, summarized in Table 2. A data comparison from mentioned sources and conducted researches provides a picture of changes over more than 60 years. The values of yearly average temperatures obtained in this way can be used for trends determination. It is revealed that the difference in values according to their average readings between the first two is $1{ }^{\circ} \mathrm{C}$ towards cooling (Table 2, No. 1, and No. 2). The next 20 years, from the 60 s to the early $80 \mathrm{~s}$, were distinguished by stable temperature indicators (Table 2, No. 2, and No. 3). Then, there is a consistent trend in warming, which is recorded by the Standards of 1983, 2000, and 2011. The difference in yearly average temperatures between them in the first case (Table 2, No. 3, No. 4) is $0.5{ }^{\circ} \mathrm{C}$. Even after the cold peaks of 2008-2009, the yearly average temperature increased, which is shown by a difference of $0.2^{\circ} \mathrm{C}$ (Table 2, No. 4, No. 5) for the next decade. Averaging of temperature values for 2012 show an increase in temperature by $0.4{ }^{\circ} \mathrm{C}$ (Table 2, No. 5, No. 6), and in 2019 the temperature was already $0.5{ }^{\circ} \mathrm{C}$ (Table 2, No. 6, No. 7). As a result of the analysis, it has been concluded that the yearly average temperature 
values in Lviv have increased by $1.6{ }^{\circ} \mathrm{C}$ over the past 40 years (Table 2, No. 3, No. 7). Thus, we have made sure the warming at the meso-climatic level is real and determined its intensity which is $-0.9{ }^{\circ} \mathrm{C}$ (concerning the current regulatory values). To justify architectural solutions, the correlation analysis of initial temperature conditions must be performed exactly on such a gradient in energy calculations. The author has also conducted a study on wind and humidity conditions and revealed the dynamics of their changes during the earlier period.

Table 2

Temperature changes dynamics in Lviv

\begin{tabular}{|c|c|c|c|c|c|}
\hline No. & Reference source & Year & $\begin{array}{c}\text { The yearly average } \\
\text { temperature value }\end{array}$ & $\begin{array}{c}\text { Reference } \\
\text { temperature } \\
\text { (cold pentad) }\end{array}$ & $\begin{array}{c}\text { The highest } \\
\text { temperature of the } \\
\text { warm period }\end{array}$ \\
\hline 1 & 2 & 3 & 4 & & 6 \\
\hline 1 & $\begin{array}{c}\text { Snip II-A. 6-62 } \\
\text { (GKSM SSSR PDS, 1963) }\end{array}$ & 1963 & 7.7 & -16 & 36 \\
\hline 3 & $\begin{array}{c}\text { SNiP II-A. 6-72 } \\
\text { (GKSM SSSR PDS, 1973) }\end{array}$ & 1973 & 6.7 & -20 & 37 \\
\hline 4 & $\begin{array}{c}\text { SNiP 2.01.01-82 } \\
\text { (GKSM SSSR PDS, 1983) }\end{array}$ & 1983 & 6.7 & -20 & 37 \\
\hline 5 & $\begin{array}{c}\text { SNiP 23-01-99 } \\
\text { (Gosstroy Rossii, 2000) }\end{array}$ & 2000 & 7.2 & -20 & -27 \\
\hline 6 & $\begin{array}{c}\text { DSTU-N B V.1.1-27:2010. } \\
\text { (Minrehionbud Ukrainy, 2011) }\end{array}$ & 2011 & 7.4 & -20 & 28 \\
\hline 7 & $\begin{array}{c}\text { ( Larysa Shuldan, 2021 } \\
\text { By the Weather Archive of Lviv } \\
\text { (aeroport)(TOV “Rozklad Pohody", 2020) }\end{array}$ & $\begin{array}{c}2009- \\
2012\end{array}$ & 7.8 & -17 & 27 \\
\hline $\begin{array}{c}\text { ( Larysa Shuldan, 2021 } \\
\text { By the Weather Archive of Lviv } \\
\text { (aeroport)(TOV “Rozklad Pohody", 2020) }\end{array}$ & $\begin{array}{c}2012- \\
2020\end{array}$ & 8.3 & -17 & \\
\hline
\end{tabular}

In 2019, a group of Swiss researchers found out how much cities can be changed in response to global climatic shifts. They found a general trend for cities in the northern hemisphere that move into warmer conditions at an average speed of $\sim 15-20 \mathrm{~km}$ per year (Bastin et al., 2019), (Beniston, 2014). The cities' geographical shift demonstration (Fitzpatrick \& Dunn, 2019) helps to understand and anticipate the effects of changes in their architecture. In this paradigm, we can assume that the climate of Lviv $\left(49^{\circ} 50^{\prime} \mathrm{N}\right)$ will be similar to the current climate of Bucharest, Bordeaux, or Bologna $(\sim 45 \mathrm{~N})$ by 2050. And the changes outlined in such a way can provide a unique opportunity to develop strong recommendations for responding and addressing their consequences. Additional risks continue to be recognized as climate changes by the impact on human health. Also, they predict the application of measures to create a comfortable environment (Haines \&, Ebi, 2019).

\section{Conclusions, proposals, and prospects for further research}

Today, the global climate system shows signs of rapid changes which is called a Climatic Transition in specialized literature. Climate change scenarios for a period comparable with the estimated lifetime of 100 years buildings do not have strong certainty. The trend of warming for the period up to 2050 has been confirmed.

The rate of warming and the geographical shift of cities causes the emergence of architectural concepts that are not typical for some regions. The adaptability of architecture to climatic changes should be developed in three main directions: 1 - the use and increase of climate properties benefits for humans; 
2 - neutralization or elimination of their adverse manifestations (protection against temperature rise, flooding, wind perturbations, etc.); 3 - reduction of human-induced disturbance (greenhouse gas emissions reduction, environmental friendliness, and energy saving). To do this, the list of architectural techniques and tools should be expanded and supplemented based on fundamental researches.

The research on the dynamics of the main climatic variables change has been based on data from standards, reference, and research literature with an averaging period of observation data from 1950 to 2008 and own surveys with linear averaging of parameters from 2009 to 2012 and from 2012 to 2020. Over the past 40 years, the yearly average temperature in Ukraine has increased by $1.5^{\circ} \mathrm{C}$. The warming intensity was calculated at the meso-climatic level (for Lviv) which is equal to $0.9{ }^{\circ} \mathrm{C}$ (in comparison with the indicators of the current standard dated from 2000). To justify architectural solutions, the correlation of initial temperature conditions must be performed exactly on such a gradient. It has been proposed to add the appropriate data to the regulatory documents.

The improving correlation of the energy efficiency of the architectural concepts with current and promising external microclimatic conditions determined the direction of further scientific and practical comprehensive researches of architectural planning and spatial organization of public buildings, taking into account trends and differences in climatic conditions in the regions of Ukraine.

\section{References}

Vitruviy, 1936. Desyat knig ob arhitekture. Kniga I. Glava I. Obrazovanie arhitektora. Istoriya antichnoy arhitekturyi. [online] Totalarch. Available at: <http://antique.totalarch.com/vitruvius/1/1> [Accessed date: May 12, 2019].

Shcherbakivskyi, V., 1910. Arkhitektura u rizhnykh narodiv i na Ukraini. Lviv-Kyiv: “Zahalna Drukarnia”. P. 5.

Dyda, I., 2009. Ekologichni osnovy tradycijnoji ukrajinskoji arkchitektury. Lviv : Natsionalnyj universytet "Lvivska politehnika".

Gusev, N. M., 1983. Osnovyi stroitelnoy fiziki: Uchebnik dlya vuzov. Moskva : Stroyizdat. P. 440.

Obolenskiy, N. V., red., 2005. Arhitekturnaya fizika: Uchebnik dlya vuzov, spets. A-87 “Arhitektura”. Moskva : Arhitektura-S". P. 448.

Myagkov, M. S., Alekseeva, L. I., 2016. Arhitekturnaya klimatografiya. Moskva: Infra-M. P. 356.

Apatenko, T. M., red., 2011. Konspekt lektsii z dystsypliny "Budivelna fizyka. Klimatolohiia" (dlia studentiv 4 kursu dennoi formy navchannia napriamu pidhotovky 6.060102 - "Arkhitektura" (eksperyment).Kharkiv: Kharkivska natsionalna akademiia miskoho hospodarstva. P. 98.

Shuldan, L. O., 2006. Problemy arkhitekturnoi klimatolohii u skladi kursu 'Arkhitekturna fizyka'.

Foster N., 2005. Works 2. Norman Foster On Architecture + Sustainability. Catalyst. [online] London: Prestel. Available at: $<$ https://www.catalystreview.net/norman-foster-on-architecture-sustainability/?fbclid=IwAR2HHVJ1RONmPJVr49m4fZCy-

eFH71SybMs9sIzJrb8fVrpAl4MUigZM9uQ> [Accessed date: December 18, 2018]

Minrehionbud Ukrainy, 2011. DSTU-N B V.1.1-27:2010. Zakhyst vid nebezpechnykh heolohichnykh protsesiv, shkidlyvykh ekspluatatsiinykh vplyviv, vid pozhezhi. Budivelna Klimatolohiia. Kyiv.

Larrochelle, J.-J., 2015. Les réponses de l'architecture au climat local, Le Monde, 20 Nov. [online] Available at: $<$ https://www.lemonde.fr/cop21/article/2015/11/27/les-reponses-de-l-architecture-au-climat-local_4819327_4527432.html>

[Accessed date: May 3, 2018].

Stronskyi, L. M., 2006. Shcho take hlobalne poteplinnia - blef chy realnist? ELEKTROpanorama, 7, 8.

Weart, S .R., 2003. The Discovery of Global Warming. Harvard University Press.

Boichenko, S. H., 2007. Kvaziperiodicheskie kolebaniya prizemnoy temperaturyi Severnogo polushariya $v$ poslednem tyisyacheletii. Dopovid. NAN Ukrainy, 6, P. 105-111.

Burroughs, W., ed., 2003. Climate: Into the 21st Century. Cambridge: Cambridge University Press. P. 240.

Akimenko, T. A., Aleksandrov, S. I., Ananev, G. S., Babkin, V. I., Badyukova E. N., 2006. Sovremennyie globalnyie izmeneniya prirodnoy sredyi: $v 2$ tomah. Moskva : Nauchnyiy mir.

Krenke, A. N., Chernavskaya, M. M., Brazdil, R., Rauner, Yu. L., Zolotokryilin, A. N., 1995. Izmenchivost klimata Evropyi $v$ istoricheskom proshlom. Moskva : Nauka.

Kim, H., An, S., 2013. On the subarctic North Atlantic cooling due to global warming. Theoretical and Applied Climatology, P. 9-19. 
National Research Council of The National Academies, 2010. Advancing the Science of Climate Change. [online] Washington, DC: The National Academies Press, pp. 204-216. P. 223. Available at: $<$ https://www.nap.edu/read/12782/chapter/1> [Accessed date: June 25, 2018].

NRC, 2008. Understanding and Responding to Climate Change. Board on Atmospheric Sciences and Climate, US National Academy of Sciences. P. 2.

Alloisioa, B. L., Farniaa, B., Khoroshiltsevaan, M., 2013. The 2013 ICCG Climate Think Tank Ranking. Methodological Report. Venice, Italy: International Center for Climate Governance.

McGann, James G., 2020. 2019 Global Go To Think Tank Index Report. Global Go To Think Tank Index Reports. [online]. Available at: $<$ https://repository.upenn.edu/think_tanks/17> [Accessed date: August 27, 2020].

United Nations, 2020. 2019 second hottest year on record, UN confirms. UN News. [online]. Available at: $<$ https://news.un.org/en/story/2020/01/1055392> [Accessed date: January 18, 2020].

European Commission, 2009. European Climate Change Programme. [online]. Available at: $<$ https://www.eubusiness.com/ topics/ environ/eccp> [Accessed date: March 26, 2019]

European Commission, 2019. Commission plans legislative framework to ensure the EU meets its target for cutting $\mathrm{CO}_{2}$ emissions from cars. [online]. Available at: $<$ https://ec.europa.eu/clima/policies/transport/vehicles/regulation_en\#tab-0-1 $>$ [Accessed date: March 26, 2019].

Peeters, M., Deketelaere, K., 2006. EU Change Climat Policy: The Challenge of New Regulatory. Global and European temperature. European Environment Agency. [online]. Available at: $<$ https://www.eea.europa.eu/data-and-maps/indicators/globaland-european-temperature-9/assessment $>$ [Accessed date: June 14, 2019].

Minrehionbud Ukrainy, 2017. DBN V.2.6-31:2016 Teplova izoliatsiia budivel. Kyiv.

Tsentralna heofizychna observatoriia imeni Borysa Sreznevskoho, 2020. Karty serednomisiachnoi temperatury povitria ta opadiv po Ukraini.[online]. Available at: <http://cgo-sreznevskyi.kiev.ua/index.php?fn=maps-ukraine\&f=php\&p=1> [Accessed date: February 2, 2020].

Ukrainskyi hidrometeorolohichnyi instytut, 2013. Zvit pro naukovo-doslidnu robotu. Rozroblennia stsenariiv zminy klimatychnykh umov $v$ ukraini na seredno- ta dovhostrokovu perspektyvu z vykorystanniam danykh hlobalnykh ta rehionalnykh modelei. [online]. Available at: $<\mathrm{https} / / / \mathrm{uhmi}$.org.ua/project/rvndr/climate.pdf $>$ [Accessed date: January 18, 2021].

Ministerstvo ekolohii ta pryrodnykh resursiv Ukrainy 2017. Kontseptsiia realizatsii derzhavnoi polityky u sferi zminy klimatu na period do $2030 \mathrm{roku}$. [online]. P. 1. Available at: $<$ https://menr.gov.ua/news/32001.html $>$ [Accessed date: May 23, 2018].

Shuldan, L. O, 2002. Klimatolohichnyi analiz raionu budivnytstva. Zavdannia i metodychni vkazivky do kontrolnohrafichnoi roboty B-1 z kursu "Budivelna fizyka" dlia studentiv napriamku 1201 - napriamu "Arkhitektura". Lviv: Vydavnytstvo Natsionalnoho universytetu "Lvivska politekhnika".

Kinash, R. I., Burnaiev, O. M., 2001. Temperaturnyi rezhym povitria i hruntu v Ukraini. Lviv: Vydavnytstvo naukovotekhnichnoi literatury.

Shuldan, L. O., Yatsiv, M. B., 1998. Zaoshchadzhennia enerhii arkhitekturnymy zasobamy. Mizhnarodna naukovotekhnichna konferentsiia “Zhytlo enerhiia ekolohiia”. Lviv DU “Lvivska politekhnika”. P. 72-76.

Gosudarstvennyiy Komitet Soveta Ministrov SSSR Po Delam Stroitelstva, 1963. SNiP II-A.6-62 Stroitelnaya klimatologiya i geofizika. Moskva: Gosudarstvennoe Izdatelstvo literaturyi po stroitelstvu, arhitekture i stroitelnyim materialam,

Gosudarstvennyiy Komitet Soveta Ministrov SSSR Po Delam Stroitelstva, 1973. SNiP II-A.6-72 Stroitelnaya klimatologiya i geofizika. Moskva: Stroyizdat.

Gosudarstvennyiy Komitet Soveta Ministrov SSSR Po Delam Stroitelstva, 1983. SNiP 2.01.01-82 Stroitelnaya klimatologiya i geofizika. Moskva: Stroyizdat.

Gosstroy Rossii, 2000. SNiP 23-01-99. Stroitelnaya klimatologiya. Moskva: GUP TsPP Gosstroya Rossii.

Minbud Ukrainy 2006. DBN 1.2.2-2006 Systema zabezpechennia nadiinosti ta bezpeky budivelnykh obiektiv. Navantazhennia i vplyvy. Kyiv.

Skrynyk O. A., Skrynyk O. Ya., 2011. Vidnovlennia propuskiv u chasovykh riadakh meteorolohichnykh pokaznykiv. Naukovi pratsi UkrNDHMI 260. P. 46-53.

TOV "Rozklad Pohody" 2020. Shchodennyk pohody u Lvovi (aeroport). [online]. Available at: $<$ http://rp5.ua/\%D0\%90\%D1\%80\%D1\%85\%D1\%96\%D0\%B2_\%D0\%BF\%D0\%BE\%D0\%B3\%D0\%BE\%D0\%B4\%D0\%B8_\%D $1 \% 83 \% \mathrm{D} 0 \% 9 \mathrm{~B} \% \mathrm{D} 1 \% 8 \mathrm{C} \% \mathrm{D} 0 \% \mathrm{~B} 2 \% \mathrm{D} 0 \% \mathrm{BE} \% \mathrm{D} 0 \% \mathrm{~B} 2 \% \mathrm{D} 1 \% 96$ (\%D0\%B0\%D0\%B5\%D1\%80\%D0\%BE\%D0\%BF\%D0\%BE $\% \mathrm{D} 1 \% 80 \% \mathrm{D} 1 \% 82>$ [Accessed date: from 2012 to 2020$]$.

Bastin, J-F., Clark, E., Elliott, T., Hart, S., van den Hoogen, J., Hordijk, I., et al. 2019. Understanding climate change from a global analysis of city analogues. PLoS ONE, 14(7). [online]. Available at: $<$ https://doi.org/10.1371/journal.pone.0217592>[ Accessed date: 21.01.2021].

Beniston, M., 2014. European isotherms move northwards by up to $15 \mathrm{~km}$ year -1: using climate analogues for awarenessraising. Int J Climatol, 34, 1838-1844. 
Fitzpatrick, M.C., Dunn, R.R., 2019. Contemporary climatic analogs for 540 North American urban areas in the late 21st century. Nature Publishing Group, 10, 614.

Haines, A, Ebi, K., 2019. The Imperative for Climate Action to Protect Health. The New England Journal of Medicine, 380. P. 263-273.

\author{
Лариса Шулдан \\ Канд. арх., доцент кафедри архітектурного проектування та інженерії, \\ Начіональний університет “Львівська політехніка", Львів \\ e-mail: shuldanlarisa@gmail.com \\ orcid: 0000-0003-4171-9807

\section{ПОКРАЩЕННЯ ЕНЕРГЕТИЧНОЇ ЕФЕКТИВНОСТІ АРХІТЕКТУРНИХ РІШЕНЬ В КОНТЕКСТІ КЛІМАТИЧНИХ ЗМІН}

\begin{abstract}
Анотація. 3в'язки між кліматичними умовами та архітектурою будівель і містобудівних утворень розкривають у частині архітектурної фізики - архітектурній кліматології. Сьогодні світова кліматична система демонструє ознаки стрімких змін, що у спеціальній літературі останнім часом обережно названо “кліматичним переходом”. У статті кліматичні тенденчії проаналізовано в різних територіальних (глобальних, макрокліматичних, мезокліматичних та мікрокліматичних) та часових межах (історичний огляд; сучасний стан; довгострокова, середньострокова та короткострокова перспективи). В результаті їх опраиювання, обтрунтованих даних на перспективу, співвідносну $з$ орієнтовним терміном життя будівель (100 років), не виявлено. Тож, за основу взято найбільш ймовірні середньострокові прогнози до 2050 року. Авторська участь у розробиі Держстандарту “Будівельна кліматологія” 2011 р. спонукала до продовження досліджень та виявлення тенденцій кліматичних змін у мезокліматичному масштабі. Проведено аналіз даних нормативних джерел від 60-х років минулого століття (1963, 1973, 1983, 2000, 2011 за даними спостережень від 1950 по 2008 рр.) та продовженні дослідження з лінійним усередненням з 2009 до 2019 р. Порівняння отриманих даних надає картину динаміки змін показників кліматичних режимів (температурного, вологісного, вітрового) за майже 70 років. Оиінена мінливість значень основних параметрів в цүілому на території України. На підставі ретроспективних досліджень та аналізі актуальних даних визначена динаміка змін основних кліматичних параметрів для міста Львова. Сформульовано основні вимоги до архітектурних вирімень у різних кліматичних умовах України. Проведено кореляцію покращення енергоефективності архітектурних рімень з актуальними зовнішньо мікрокліматичними умовами. Запропоновано внести відповідні дані до нормативних документів.
\end{abstract}

Ключові слова: архітектурна кліматологія, кліматичний перехід, будівельна кліматологія, покращення енергоефективності архітектурних рішень, Львівська політехніка, архітектура громадських будівель. 